\title{
Portable chlorophyll meter for the quantification of photosynthetic pigments, nitrogen and the possible use for assessment of the photochemical process in Carica papaya $\mathrm{L}$.
}

\author{
Alena Torres Netto ${ }^{1 *}$, Eliemar Campostrini ${ }^{1}$, Jurandi Gonçalves de Oliveira ${ }^{1}$ \\ and Osvaldo Kiyoshi Yamanishi²
}

\begin{abstract}
${ }^{1}$ Laboratório de Melhoramento Genético Vegetal - Centro de Ciências e Tecnologias Agropecuárias, Universidade Estadual do Norte Fluminense, CEP 28013-600, Campos dos Goytacazes, RJ, Brasil; ${ }^{2}$ Universidade de Brasilia, FAV- Fruticultura, CP 04508, CEP 70910-970, Asa Norte, Brasilia, DF, Brasil; *Corresponding author: alena@uenf.br

Received: 19/04/2002, Accepted: 20/07/2002
\end{abstract}

The techniques utilized to extract chlorophyll from plant materials are destructive and based on methods that use organic solvents. This study proposes the non-destructive quantification of chlorophyll and nitrogen concentration using a portable chlorophyll meter (SPAD-502). Further, was possible to establish relationships between chlorophyll fluorescence and SPAD-502 values. This methodology could save time, space and resources, and could be used for analysis of the photosynthetic processes. Papaya leaves (Solo and Formosa groups) of different ages were collected from 15-month-old plants cultivated in a commercial field in São Francisco de Itabapoana, Rio de Janeiro State $\left(41^{0}: 15 \mathrm{~W} ; 21^{0}: 27 \mathrm{~S}\right)$. Correlations were established between the chlorophyll content and carotenoids extracted in DMSO, nitrogen content, a chlorophyll $a$ fluorescence $\left(F \phi, F_{\text {max }}, F_{v} / F_{\text {max }}, q_{N}, q_{P}, N P Q\right)$ with readings from SPAD-502 taken on papaya leaves of different ages. The results show that while the $q_{p}$ and the $F_{v} / F_{\text {max }}$ increased with SPAD-502 readings of up to 40 , the $q_{N}$ and $N P Q$ variables decreased. The $F_{\max }$ presented a direct linear correlation with the SPAD-502 values while the $F \phi$ variable did not correlate with the SPAD-502 values. The portable chlorophyll meter was shown to be useful for nondestructive determination of photosynthetic pigments (chlorophyll and carotenoids) and can be used indirectly in interpretation of the photochemical process in Carica papaya L. leaves.

Key words: nutrient content, photosynthetic pigments, SPAD-502.

Medidor portátil de clorofila: determinação dos teores de pigmentos fotossintéticos, nitrogênio e possibilidades de uso nas interpretações do processo fotoquímico em Carica papaya L.: Os métodos utilizados para a extração de clorofila em material vegetal são destrutivos e baseiam-se nos que utilizam solventes orgânicos. Este trabalho propõe a quantificação não-destrutiva dos teores de clorofila e nitrogênio por meio do SPAD-502. Ainda, foi possível estabelecer uma relação entre a fluorescência e os valores obtidos pelo SPAD-502. Tal método poderá proporcionar uma substancial economia de tempo, espaço e recursos, contribuindo na melhoria das interpretações dos processos fotossintéticos. Para tanto, utilizaram-se folhas de mamoeiro (grupos 'Solo' e 'Formosa') de diferentes estádios de desenvolvimento, coletadas de plantas com 15 meses de idade, cultivadas em plantio comercial no município de São Francisco de Itabapoana/RJ. Estabeleceram-se correlações entre os teores de clorofila e carotenóides extraídos em DMSO, os de nitrogênio, a fluorescência da clorofila $a\left(F \phi, F_{\text {max }}, F_{v} / F_{\text {max }}, q_{N}, q_{P}, N P Q\right)$ e as leituras pelo SPAD-502 em folhas da espécie em estudo,

Abreviations: $(F \phi)$ : minimal fluorescence; $\left(F_{\max }\right)$ : maximal fluorescence; $\left(F_{v} / F_{\max }\right)$ : ratio of variable to maximal fluorescence-quantum efficiency of open photosystem II centres- quantum yield; $\left(q_{p}\right)$ : photochemical quenching; $\left(q_{N \mathrm{e}} N P Q\right)$ : non-photochemical quenching; $\left(Q_{a}\right)$ : primary quinone acceptor of photosytem II; (PQ pool): the photochemically reducible pool of platoquinone molecules; (PSII): photosystem II; (DMSO): dimethylsulphoxide; (LHCII): light harvesting complex II; $(\mathrm{Chl})$ : chlorophyll; $(\Delta p H)$ : transthylakoid proton gradient. 
dos grupos 'Solo' e 'Formosa'. Os resultados mostraram que enquanto a variável $q_{P}$ e a relação $F_{v} / F_{\max }$ foram crescentes, até leituras do SPAD-502 próximas a 40, as variáveis $q_{N}$ e $N P Q$ mostraram-se decrescentes. A variável $F_{\max }$ apresentou uma correlação linear, direta, em relação aos valores do SPAD-502, enquanto $F \phi$ não apresentou nenhuma correlação com tais valores. De acordo com os resultados, concluiu-se que o determinador portátil de clorofila poderá ser utilizado na quantificação dos pigmentos fotossintéticos (clorofilas e carotenóides) e, indiretamente, auxiliar nas interpretações do processo fotoquímico da fotossíntese em plantas da espécie Carica papaya $\mathrm{L}$.

Palavras-chave: conteúdo de nutrientes, pigmentos fotossintéticos, SPAD-502.

\section{INTRODUCTION}

Techniques utilized to extract photosynthesis pigments from plant materials are based on methods that use organic solvent such as acetone (Mckiney, 1941; Arnon, 1949; Bruisna, 1961), dimethylsulphoxide (DMSO) (Hiscox and Israelstam, 1979), methanol, petroleum ether and others (Moran and Porath, 1980; Moran, 1982; Lichtenthaler and Wellburn, 1983; Inskeep and Bloom 1985). Acetone $80 \%$ is the most used of these solvents. However, these methods require sample destruction. There can be significant losses of these pigments during the extraction process and extract dilution that can cause high variability in the results. Shoaf and Lium (1976), using DMSO, modified the extraction methodology to eliminate the squashing and centrifuge stages. The storage period of these pigments was increased by the use of this solvent so that the spectrophotometer analyses did not have to be carried out immediately after extraction.

Although high correlation was not obtained between the chlorophyll content and the photosynthesis rate (Marini, 1986), the determination of the photosynthetic pigments and their ratios are important indicators of senescence (Brown et al., 1991). Further, the losses in chlorophyll content are associated with environmental stress factors (Hendry and Price, 1993). According to these authors, variations in the total chlorophyll/carotenoids ratio are good indicators of stress in plants.

The SPAD-502 meter is presently available on the market, and is used for associating the relative chlorophyll content of leaves with the one-dimensional values established by the meter (green color intensity index). This meter takes instant readings without having to destroy the plant tissue sample and the reading is performed in a very short time (2 s). Although this meter presents disadvantages such as small measuring area $\left(12.57 \mathrm{~mm}^{2}\right)$, the use of this meter saves time, space and resources. The readings obtained by the meter refer to the quantification of light intensity $(650 \mathrm{~nm})$ absorbed by the tissue sample. However, to determine the real concentration of the chlorophyll content in a sample, the ratio between the values obtained by the meter and the real chlorophyll content must be established. Some studies report SPAD502 reading with nitrogen content in several plant species (Smeal and Zhang, 1994, Peng et al., 1995; Balasubramanian et al., 2000) as this element is part of the chemical structure of the chlorophyll molecule. However there is no information on the use of this meter for the papaya species.

Chlorophyll fluorescence measurements are fast, precise and non-destructive and used to investigate the damage caused in the photosynthesis apparatus by various kinds of stress (Smille and Nott, 1982; Strand and Öquist, 1988; Schreiber et al., 1988; Havaux et al., 1988; Ögren 1994; Govindjee, 1995). The chlorophyll $a$ fluorescence variables provide important information on the photochemical process in photosynthesis. The $F_{V} / F_{\max }$ ratio is the most widely used of these variables in research using the fluorescence technique. This ratio is directly correlated to the photochemical efficiency of the photosystem II (PSII) for which values of $0.800 \pm 0.50$ correspond to high efficiency in the use of the excitation energy for photochemical processes (Björkman and Demmig, 1987; Bolhàr-Nordenkampf et al., 1989; Mohammed et al., 1995). The $F \phi$ variable represents the fluorescence emission from the complex antenna, even before the arrival of the photon energy to the center of the photosystem II reaction. In this state, all the reaction centers are oxidized (or "open") (Krause and Weis, 1984, 1991; Govindjee, 1995). The $\mathrm{F}_{\mathrm{m}}$ variable is emitted when all the plastoquinone pool $(P Q)$ are in a reduced state and unable to transfer electrons between the photosystem II reaction center and the $P Q$ pool. In this condition, all the 
energy absorbed will be dissipated as fluorescence thus giving maximal fluorescence (Krause and Weis, 1984, 1991; Govindjee, 1995). Other variables have been used with due interpretations, photochemical quenching $\left(q_{p}\right)$ is associated with photosynthetic metabolism of carbon and varies numerically from 0 (closed PSII reaction centers, $Q_{a}$ complete reduced) to 1 (PSII reaction centers open, $Q_{a}$ completed oxidized). This variable represents, in general terms, the capacity of the photochemical/biochemical process to re-oxidize $Q_{a}$, that is, the excitation energy dissipation in the form of electron transference (BolhàrNordenkampf et al., 1989). Non-photochemical quenching $\left(q_{N}\right)$ is directly related to the non photochemical reaction of excitation energy dissipation (Krause and Weis, 1991) and is constructed from some components. Of these, three are of major importance: 1) " $q_{e}$ " quenching dependent on energy - results from energy dissipation in non-radiant heat form, which is related to the formation of the transthylacoid proton gradient $(\Delta p H)$ (Krause and Weis, 1991); 2) " $q_{t}$ " quenching dependent on the transition state - related to the phosphorylation of the light harvesting complex II (LHCII) (Allen, 1992) and 3) " $q_{i}$ " photoinhibitory quenching - results from transformation of the PSII reaction center because of photoinhibitory processes (Schreiber and Bilger, 1992). There is another way of expressing nonphotochemical quenching that is called $N P Q$ (Bilger and Björkman, 1990). $N P Q$ has been shown to be closely related to the excess light energy which is actively dissipated by plants into heat in order to avoid photodamage (Rohacek and Bartak, 1999).

This study was carried out to establish a possible correlation between the photosynthetic pigment contents extracted in DMSO, the nitrogen content and chlorophyll fluorescence variables with SPAD-502 readings on Solo and Formosa group papaya tree leaves.

\section{MATERIAL AND METHODS}

Plant material and cultivation conditions: Papaya leaves of different ages (Solo and Formosa groups) were collected from 15-month-old plants cultivated in a commercial plantation in São Francisco de Itabapoana, RJ, Brazil (lat. $21^{\circ} 27^{\prime} \mathrm{S}$; Long $\left.41^{\circ} 15^{\prime}\right)$. The plants were fertilized and irrigated by the usual management methods used in the plantations. The leaves were transported in insulated boxes sheltered from light and taken to the Setor de Fisiologia Vegetal at Centro de Ciências e Tecnologias Agropecuárias at the Universidade Estadual do Norte Fluminense, Campos dos Goytacazes, RJ.

Photosynthetic pigment analysis: After collecting the leaves, leaf discs with a known area $\left(169.72 \mathrm{~mm}^{2}\right)$ were extracted. The mean of five SPAD-502 readings by the portable chlorophyll meter (SPAD-502, Minolta, Japan) on each disc were obtained. Approximately 50 leaf discs were used and the values obtained by the meter varied from 4 to 60 . The CurvExpert ${ }^{\circledR}$ program was used to fit the suitable mathematical model to the data set (Photosynthetic pigments versus SPAD-502 readings).

After reading with the meter, each disc was cut into smaller pieces and placed in a test tube containing $5 \mathrm{~mL}$ of DMSO. The test tubes were incubated at $70{ }^{\circ} \mathrm{C}$ for 30 min (Hiscox and Israestam, 1978). After cooling the liquid extract, a $3 \mathrm{~mL}$ aliquot was removed for reading in a spectrophotometer at 470, 646 and $663 \mathrm{~nm}$. The chlorophyll $a$ and $b$ contents, the ratio between chlorophyll a and chlorophyll b content and the carotenoids were determined following the equation proposed by Wellburn (1994).

Nitrogen determination: Leaf discs with an area of 525.02 $\mathrm{mm}^{2}$ were removed in each sample, in the laboratory, and five readings were taken on each disc, with the SPAD-502. The discs were placed in six groups containing 25 discs in each group according to the reading ranges $(0-10,10-20$, 20-30, 30-40, 40-50, 50-60). Each group of 25 discs were put in paper bags, placed in a forced air chamber at $70{ }^{\circ} \mathrm{C}$. After $48 \mathrm{~h}$ the material was ground in a mill (Wiley) with a 20 mesh sieve and stored in hermetically sealed flasks for later analysis. The Nessler method (Jackson, 1958) was used to determine the nitrogen after oxidizing the plant material by sulfuric digestion.

Chlorophyll fluorescence determination: After measuring with the SPAD-502, the room temperature chlorophyll fluorescence measurements were carried out on the leaf discs using the mini portable pulse amplitude modulation fluorometer (MINI-PAM, Walz, Effeltrich, Germany). The leaf discs were pre-darkened for $30 \mathrm{~min}$ so that the all reaction centres were "open" (all primary acceptors oxidized) and heat dissipation was minimal. After dark adaptation, the fluorescence variables $F \phi, F_{\max }, F_{v} / F_{\text {max }}$, $q_{N}, q_{P}$ e NPQ were analyzed (Schreiber et al., 1994). The 
minimal fluorescence $(F \phi)$ was obtained with modulated low intensity light $\left(<0.1 \mu \mathrm{mol} . \mathrm{m}^{-2} \cdot \mathrm{s}^{-1}\right)$ so as not to affect the variable fluorescence. The maximal fluorescence $\left(F_{\text {max }}\right)$ was determined by a $0.8 \mathrm{~s}$ long saturating light pulse $(6,800$ $\mu \mathrm{mol} . \mathrm{m}^{-2} \cdot \mathrm{s}^{-1}$ ) with $20,000 \mathrm{~Hz}$ frequency. The variable fluorescence was determined by the difference between $F \phi$ and $F_{\text {max }} . \quad F_{v} / F_{\text {max }}$ ratio was obtained from the $\mathrm{F}_{\mathrm{V}}$ and $\mathrm{F}_{\mathrm{m}}$ and represent potential maximal PSII quantum yield (Schreiber et al., 1994). The quenching coefficients was defined as $q_{P}=\left(F m^{\prime}-F\right) /\left(F m^{\prime}-F \phi\right), q_{N}=\left(F m-F m^{\prime}\right) /(F m-$ $F \phi)$ and $N P Q=\left(F m-F m^{\prime}\right) / F m^{\prime}$ (Schreiber et al., 1994). The characteristic fluorescence levels and quenching coefficients was defined in agreement with a proposal for standard nomenclature at a fluorescence workshop (Van Kooten and Snel, 1990).
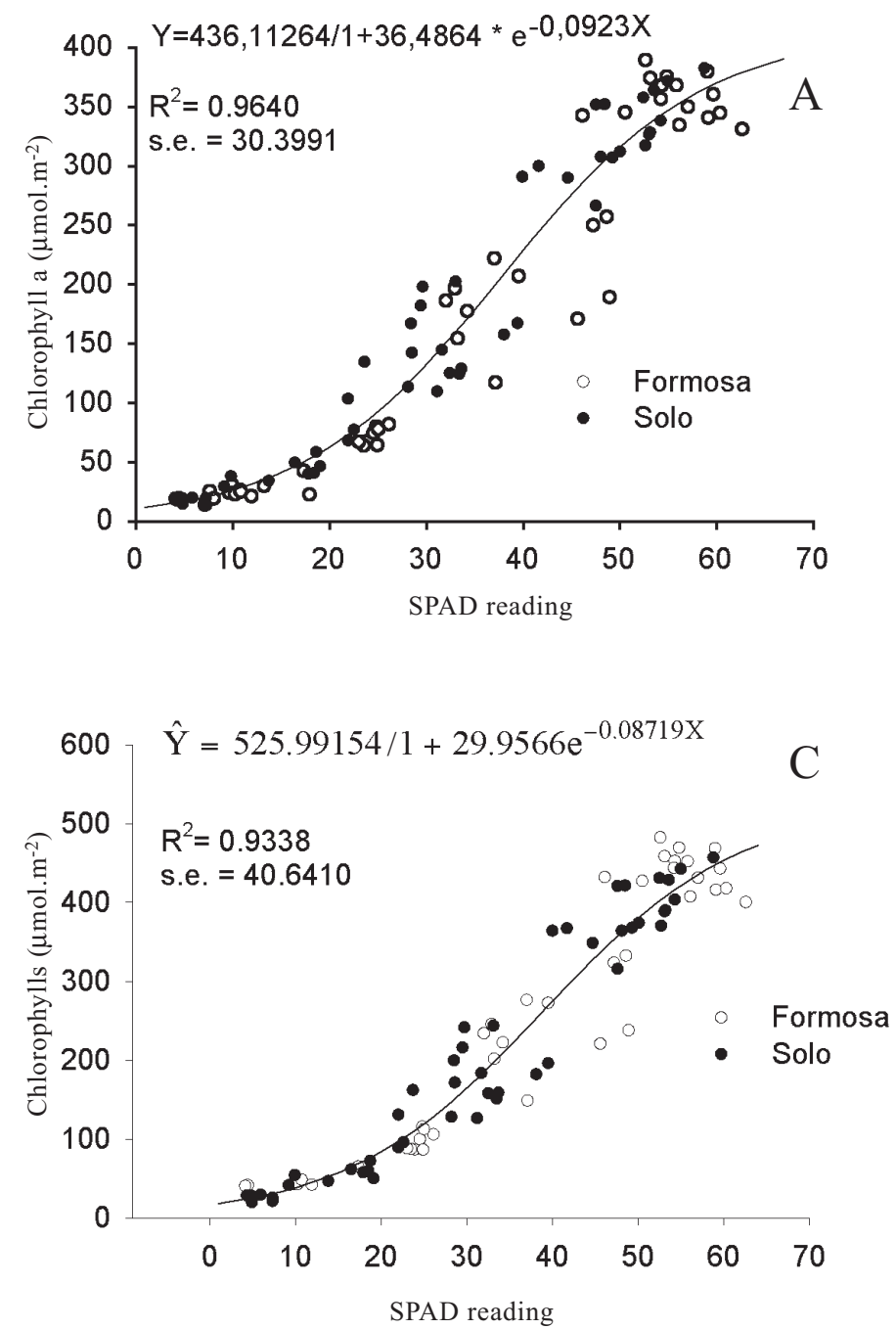

\section{RESULTS AND DISCUSSION}

Figures 1 and 2 refer to the relationship among the SPAD-502 readings, the photosynthesis pigment contents and their relationship to the 'Solo' and 'Formosa' papaya leaves. Determination coefficient values ranged from 0.76 to 0.96 in all the models. Relationships among the total chlorophyll content and the SPAD-502 readings were established in several plant species (Marquard and Tipton, 1987; Schaper and Chacko, 1991). In these studies, the fitted model was the simple linear mathematical model. In this work, were suggesting that for papaya the linear mathematical model was not the best model.

Chlorophyll $a$ is more intensely degraded than chlorophyll $b$ (Wolf, 1956). This information may explain the sharp decrease of the chlorophyll $a / b$ ratio when the SPAD-502 readings were less than 40 (figure 2).
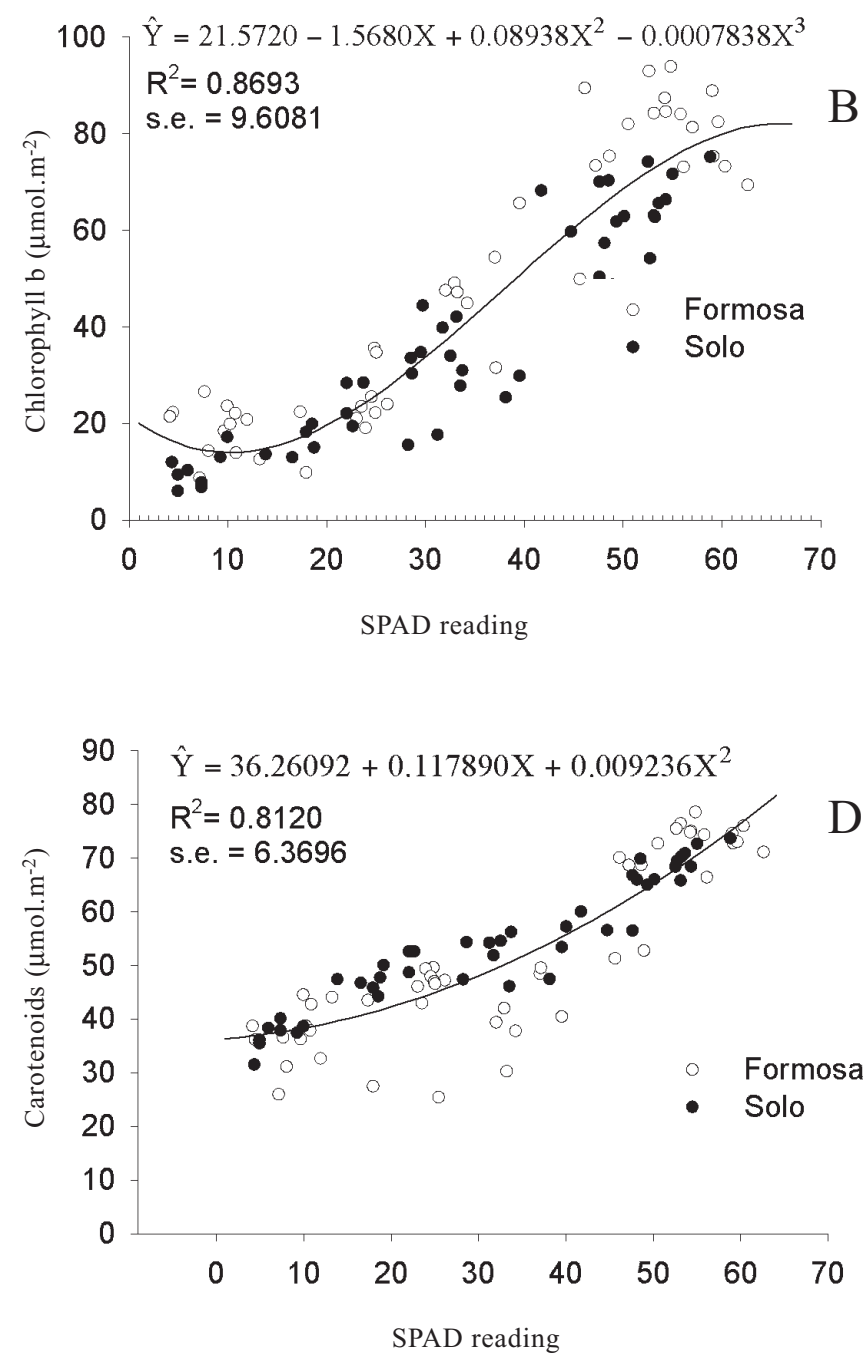

Figure 1. Relationship between SPAD-502 and chlorophyll $a$ contents (A), chlorophyll $b$ (B), total chlorophyll (C), carotenoid content (D) in papaya leaves (Carica papaya L.), Solo and Formosa groups. 

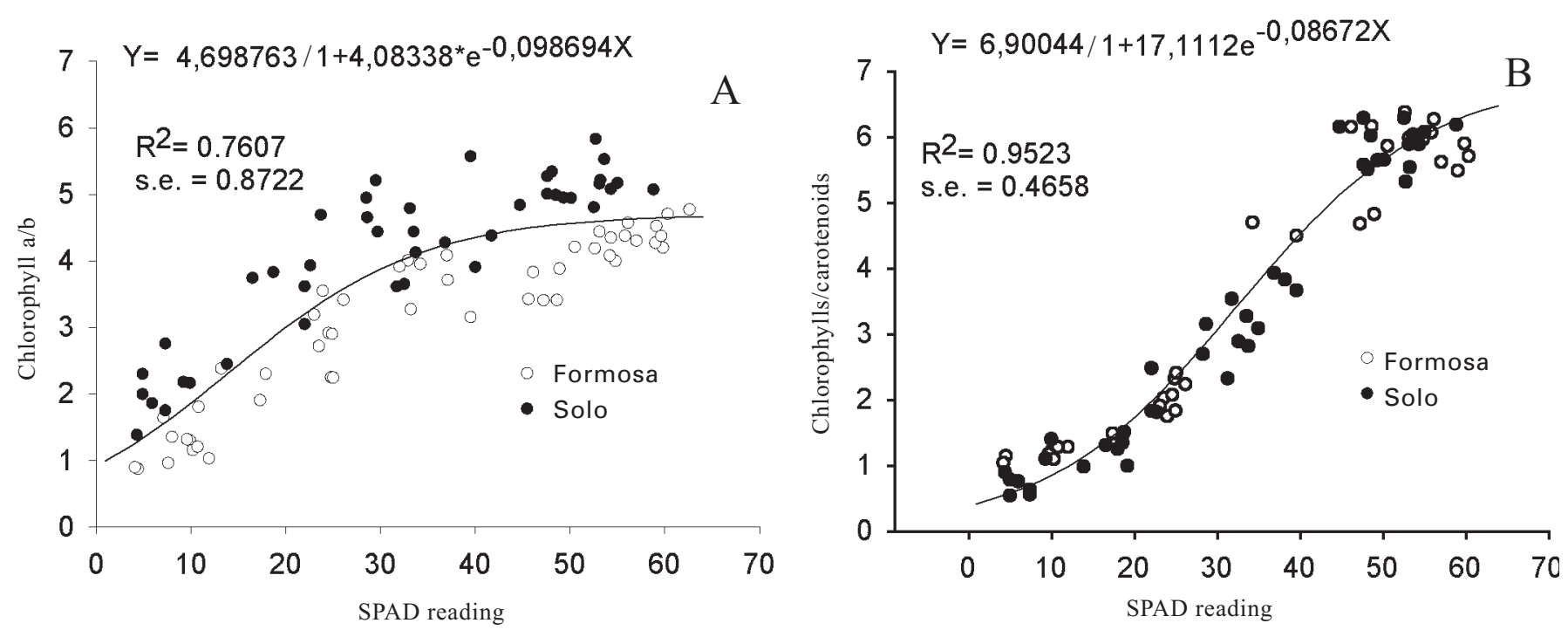

Figure 2. Relationship between SPAD-502 and chlorophyll $a / b$ rates (A), total chlorophyll/carotenoids rates (B) in papaya leaves (Carica papaya L.), Solo and Formosa groups.

Figure 3 shows the relationship for the SPAD-502 readings, the nitrogen contents and the total chlorophyll contents in both papaya groups. It was observed that the nitrogen contents were correlated to the SPAD-502 readings $\left(\mathrm{R}^{2}=0.97\right.$ and standard error $\left.=2.83\right)$. This figure shows that the decrease in the total nitrogen content fell sharply when the values obtained by the SPAD-502 were lower than 40 .

Figure 4 (A to F) shows the relationship among the SPAD-502 readings and the fluorescence variables of chlorophyll $a$. The $F \phi$ variable (figure 4A) did not present any correlation with the SPAD-502 values. The $F_{\max }$ variable (figure 4B) presented a direct linear relationship with the SPAD-502 values, along all the reading band of the portable chlorophyll meter. The $F_{\max }$ variable corresponds to the state of complete reduction of the $P Q$ and is considered proportional to the total chlorophyll content of the sample (Miranda et al., 1981). The data presented here (figure 4) showed that the photochemical process was impaired in papaya leaves from the 'Solo' and 'Formosa' groups that presented SPAD-502 values less than 40. The quantum efficiency of open photosystem II centers represented by the $F_{v} / F_{\max }$ ratio fell (figure 4C) when the SPAD-502 readings presented values less than $40 . F_{v} / F_{\text {max }}$ values less than 0.75 meant a decrease in the light efficient use by the photosystem II (Björkman and Demmig, 1987, Bolhàr-Nordenkampt et al., 1989; Mohammed et al., 1995). Furthermore, papaya leaves that presented SPAD-502 values less than 40 also showed reduced $q_{p}$ values (figure
4D), which represented a fall in the capacity of the photochemical process to re-oxidize $Q_{a}$ (BolhàrNordenkampf et al., 1989). These $q_{p}$ data indicate disturbances in the electron transport or even possible damage in the reducing power of the biochemical process. The $q_{N}$ and $N P Q$ values (figure $4 \mathrm{E}$ and $4 \mathrm{~F}$ ) fell as the SPAD-502 values increased until close to 40 . From this value, these fluorescence variables remained practically unaltered. The $q_{N}$ and $N P Q$ variables represent a fraction of the energy absorbed, such as the excitation of the photosynthesizing pigments, that is dissipated as heat or non-radioative energy (thermal energy). This dissipation

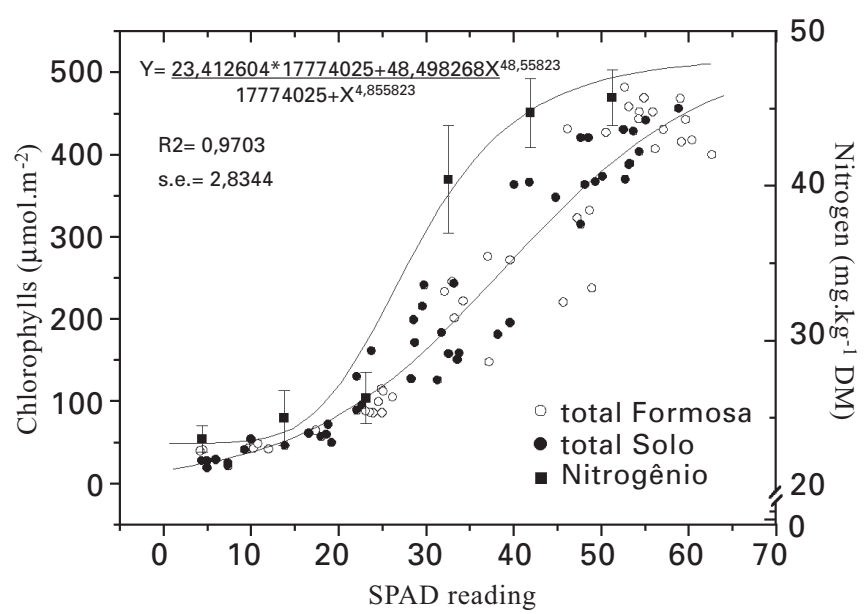

Figure 3. Relationship between total chlorophyll and nitrogen content and SPAD readings in papaya leaves (Carica papaya L.), Solo and Formosa groups. 

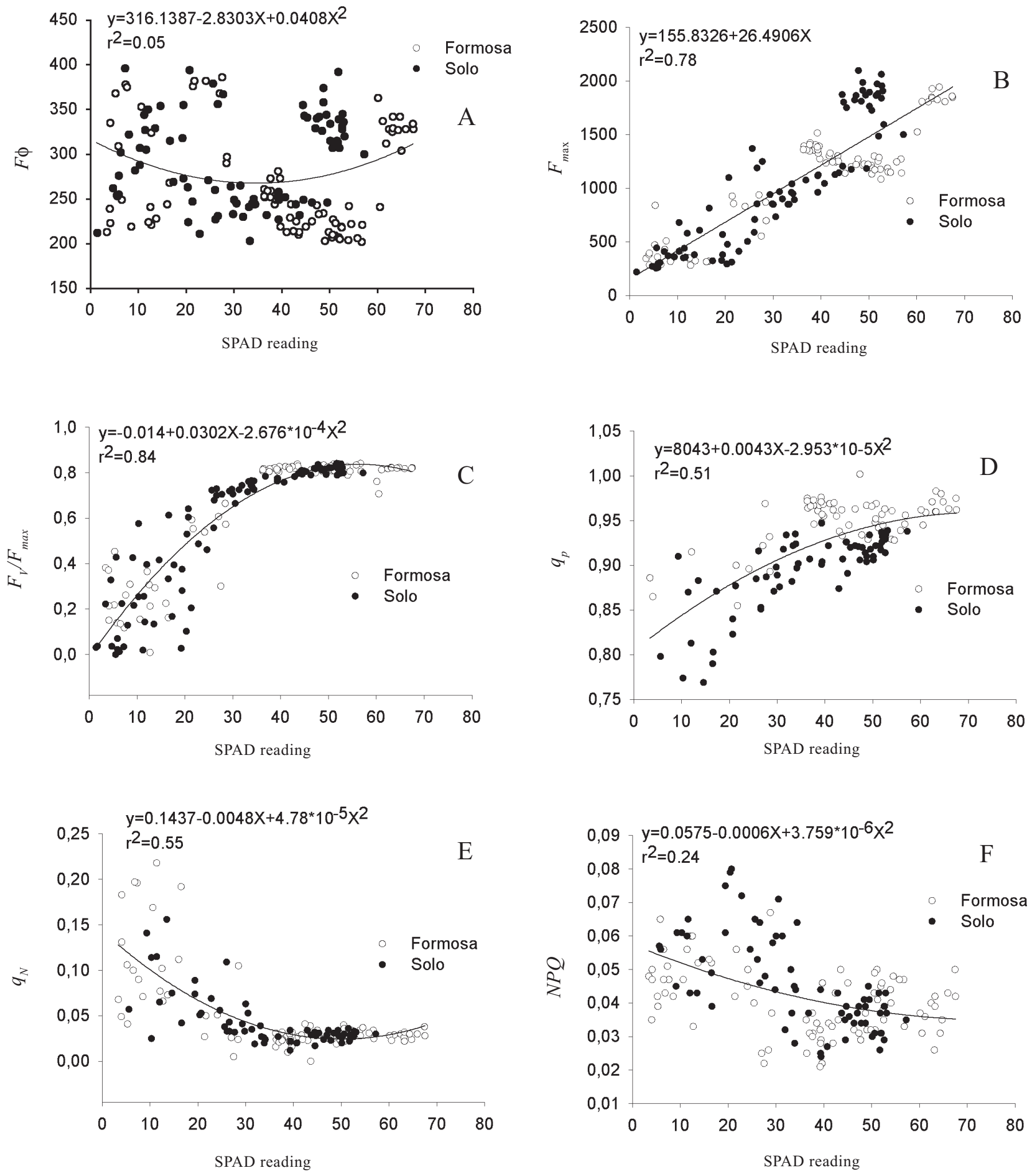

Figure 4. Relationship between SPAD-502 and minimal fluorescence $(F \phi)(\mathrm{A})$, maximal fluorescence $\left(F_{\max }\right)(\mathrm{B})$, quantum efficiency of open photosystem II centers $\left(F_{/} / F_{\max }\right)(\mathrm{C})$, photochemical quenching $\left(q_{p}\right)$ (D), non-photochemical quenching $\left(q_{N e}\right.$ and $\left.N P Q\right)(\mathrm{E}$ and F) in papaya leaves (Carica papaya L.), Solo and Formosa groups. 
process is competitive with the dissipation as photochemical activity (oxy-reduction processes). These $q_{p}$ and $N P Q$ data show that the energy was directed to other processes not related to $Q_{a}$ re-oxygenation (as shown by the decreasing values of the $q_{p}$ variable - figure 4D), probably dissipation in the form of heat. The SPAD-502 values greater than 40 are associated with high photosynthetic pigment (chlorophyll $a$ and $b$ and carotenoids) and nitrogen contents in leaves of papaya from the same groups of this study. Further, the results show that the values of the total chlorophyll/carotenoids ratio increased (between 5 and 7) with the SPAD-502 values increase above 45 , indicating the high potential of the photosynthetic capacity of this tissue (Buckland et al., 1991).

It is concluded that photosynthetic pigments determination with portable chlorophyll meter was rapid, convenient and nondestructive to papaya leaf. Values lower than 40 indicated the initial problems in the photochemical process as shown by the curves of the species under study. This fact indicates that the SPAD-502 can be used to the assessments of the photosynthetic pigment contents and total nitrogen and to assess the state of the photochemical process in papaya leaves.

Acknowledgments: We thank Dr. Richard Ian Samuels for reading of the manuscript. This study was financed by Fundação Carlos Chagas Filho de Amparo à Pesquisa do Estado do Rio de Janeiro - FAPERJ and FINEP.

\section{REFERENCES}

Allen JF (1992) Protein phosphorylation in regulation of photosynthesis. Biochim. Biophys. Acta 1098:275-335.

Arnon DI (1949) Copper enzymes in isolate chloroplasts. Polyphenoloxidases in Beta vulgaris. Plant Physiol. 24:1-15.

Balasubramanian V, Morales AC, Cruz RT, Thiyagarajan TM, Nagarajan R, Babu M, Abdulrachman S, Hai LH (2000) Adaptation of the chlorophyll meter (SPAD) technology for real-time $\mathrm{N}$ management in rice: a review. Int. Rice Res. Inst. 5:25-26.

Bilger W, Bjorkman O (1990) Role of the xanthophyll cycle in photoprotection elucidated by measurements of lightinduced absorbance changes, fluorescence and photosynthesis in leaves of Hedera canariensis. Photosyn. Res. 25:173-186.

Björkman O, Demmig B (1987) Photon yield of $\mathrm{O}_{2}$ evolution and chlorophyll fluorescence characteristics at $77 \mathrm{~K}$ among vascular plants of diverses origins. Planta 170:489-504.
Bolhàr-Nordenkampf HR, Long SP, Baker NR, Öquist G, Schreiber U, Lechner EG (1989) Chlorophyll fluorescence as a probe of the photosynthetic competence of leaves in the field: A review of current instrumentation. Func. Ecol. 3:497-514.

Brown SB, Houghton JD, Hendry GAF (1991) Chlorophyll breakdown. In: Scheer H (ed), Chlorophylls, pp. 465489. Boca Raton: CRC Press.

Bruisma J (1961). A comment on the spectrophotometric determination of chlorophyll. Biochim. Biophys. Acta 52:576-578.

Buckland SM, Price AH, Hendry GAF (1991) The role of ascorbate in drought-treated Cochlearia atlantica Pobed. and Armeria maritime (Mill.) Willd. New Phytol. 119:155-160.

Govindjee (1995) Sixty-three years since Kautsky: Chlorophyll a fluorescence. Aust. J. Plant Physiol. 22:131160.

Havaux M, Ernez M, Lannoye R (1988) Correlation between heat tolerance and drought tolerance in cereals demonstraded by rapid chlorophyll fluorescence tests. J. Plant Physiol. 133:555-560.

Hendry GAF, Price AH (1993) Stress indicators: chlorophylls and carotenoids. In: Hendry GAF, Grime JP (eds), Methods in Comparative Plant Ecology, pp.148-152. Chapman \& Hall, London.

Hiscox JD, Israelstam GF (1979) A method for the extraction of chlorophyll from leaf tissue without maceration. Can. J. Bot. 57:1332-1334.

Inskeep WP, Bloom PR (1985) Extinction coefficients of chlorophyll $\mathrm{a}$ and $\mathrm{b}$ in N.N-dimethytformamide and 80\% acetone. Plant Physiol. 77:483-485.

Jackson ML (1958) Soil chemical analysis. Prentice Hall, New Jersey.

Krause GH, Weiss E (1984) Chlorophyll fluorescence as a tool in plant physiology. II. Interpretation of the fluorescence signals. Photosynth. Res. 5:1139-157.

Krause GH, Weiss E (1991) Chlorophyll fluorescence and photosynthesis. Annu. Rev. Plant Physiol. Plant Mol. Biol. 42:313-359.

Lichtenthaler HK, Wellburn AR (1983) Determinations of total carotenoids and chlorophylls a and b of leaf extracts in different solvents. Biochem. Soc. Transac. 11:591-592.

Maquard RD, Tipton JL (1987) Relationship between extractable chlorophyll and na in situ method to estimate leaf greennes. Hortscience 22:1327.

Marini RP (1986) Do net gas exchange rates of green and red peach leaves differ? Hortscience 21:118-120.

Mckinney G (1941) Absorption of light by chlorophyll solutions. J. Biol. Chem. 140:315-322. 
Miranda V, Baker NR, Long SP (1981) Limitations of photosynthesis in different regions of the Zea mays leaf. New Phytol. 89: 79-190.

Mohammed GH, Binder WD, Gillies SL (1995) Chlorophyll fluorescence: A review of its practical forestry applications and instrumentation. Scand. J. For. Res. 10:383-410.

Moran R (1982) Formulae for determination of chlorophyllous pigments extracted with $N, N$ dimethylformamide. Plant Physiol. 69:1376-1381.

Moran R, Porath D (1980) Chlorophyll determinations in intact tissue using $N, N$-dimethylformamide. Plant Physiol. 65:478-479.

Ögren E (1994) The significance of photoinhibition for photosynthetic productivity. In: Baker NR, Bowyer JR (eds.), Photoinhibition of Photosynthesis from Molecular Mechanisms to the Field, pp. 433-447. BIOS Scientific Publischer, Oxford.

Peng S, Laza RC, Garcia FC, Cassman KG (1995) Chlorophyll meter estimates leaf area-based $\mathrm{N}$ concentration of rice. Commun. Soil Sci. Plant Anal. 26:927-935.

Rohacek K, Bartak M (1999) Technique of the modulated chlorophyll fluorescence: basic concepts, useful parameters, and some applications. Photosynthetica 37:339-363.

Schaper H, Chacko EK (1991) Relation between extractable chlorophyll and portable chlorophyll meter readings in leaves of eight tropical and subtropical fruittree species. J. Plant Physiol. 138:674-677.

Schreiber U, Bilger W (1992) Progress in chlorophyll fluorescence research: major developments during the last years in retrospect. Progress Bot. 54:151-173.

Schreiber U, Bilger W, Klughammer C, Neubauer C (1988) Application of the PAM fluorometer in stress detection.
In: Lichtenthaler HK (ed.), Applications of Chlorophyll Fluorescence, pp.151-155. Kluwer Academic Publisher, Dordrecht.

Schreiber U, Bilger W, Neubauer C (1994) Chlorophyll fluorescence as a nonintrusive indicator for rapid assessment of in vivo photosynthesis. In: Schulze ED, Caldwell MM (eds), Ecophysiology of Photosynthesis, pp. 49-70. Springer-Verlag, Heidelberg.

Shimizu T, Torikata H (1972) Studies on the Chlorophyll contend of satsuma orange leaves. J. Jap. Soc.Horticult. Sci. 41:29-36.

Shoaf TW, Lium BW (1976) Improved extraction of chlorophyll a and $b$ from algae using dimethyl sulphoxide. Limnol. Oceanogr. 21:926-928.

Smeal D, Zhang H (1994) Chlorophll meter evaluation for nitrogen management in corn. Commun. Soil Sci. Plant Anal. 25:1495-1503.

Smille RM, Nott R (1982) Salt tolerance in crop plants monitored by chlorophyll fluorescence in vivo. Plant Physiol. 70:1049-1054.

Strant M, Öquist G (1988) Effects of frost hardening, dehardening and freezing stress on in vivo chlorophyll fluorescence of scots pine seedlings (Pinus sylvestris L.). Plant Cell Environ. 11:231-238.

Van Kooten O, Snel JFH (1990) The use of chlorophyll fluorescence nomenclature in plant stress physiology. Photosynt. Res. 25:147-150.

Wellburn AR (1994). The spectral determination of chlorophyll a and b, as well as total carotenoids, using various solvents with spectrophotometers of different resolution. J. Plant Physiol. 144:307-313.

Wolf FT (1956) Changes in chlorophylls $a$ and $b$ in autumn leaves Am. J. Bot. 43:714-718. 